\title{
The US and UK in the Eyes of English Majors in the Arab World
}

\author{
Dr. Mais Qutami (Corresponding author) \\ Department of English Language and Literature \\ AlZahra College for Women, Muscat, Oman \\ P.O. Box: 3365- P.C.: 111- Airport Heights \\ Muscat, Sultanate of Oman \\ Phone: (968)-9767-1357Ｅ-mail: eternalmais@yahoo.com \\ Dr. Suha Qutami \\ Department of Instructional Services \\ Toronto District School Board \\ 10 Chichester Place, 401, Toronto, ON. \\ M1T 1G5, Canada \\ Phone: (001)-647-853-7929_E-mail: suha_qutami@yahoo.com
}

Received: 24-11- 2012

Accepted: 23-12- 2012

Published: 01-03- 2013

doi:10.7575/aiac.ijalel.v.2n.2p.8

URL: http://dx.doi.org/10.7575/aiac.ijalel.v.2n.2p.8

\begin{abstract}
The current study examines the attitudes of Jordanian female college students whose major is English language and literature towards the United States of America and the United Kingdom. It also looks into the reasons for their held beliefs about the West, the US and UK, in particular. A survey and semi- structured interviews were conducted with forty Muslim female students from various cities and villages in Jordan for this purpose. The selected students are in their final semester in the English program and have completed various courses in language and literature. In these courses, students have been mostly exposed to British and American literature throughout the four year period of their study. The study also examines whether student attitudes towards the West resemble those of the general Arab public. The findings certainly challenge the theory of the "Clash of civilizations." In fact, the results demonstrate that students have a more favourable opinion of the UK than the US and that this has everything to do with their dissatisfaction with the current American foreign policies and nothing to do with the "American way of life."
\end{abstract}

Keywords: clash of civilizations, East, West, English majors, student attitude

\section{Introduction}

Some researchers and analysts argue that a great hostility and hatred exists between the Arab Muslim world and the West on the grounds of the "Clash of civilizations" theory (Huntington,1996; Lewis, 2003). However, many surveys and studies have been conducted in the Middle East and the West to examine the public's attitude towards each other that oppose this theory. For instance, the research done by internationally respected organizations such as: the Gallup Center for Muslim Studies, Pew Research Center, Zogby International, and the Center for Strategic Studies (CSS) in Jordan suggests that Arabs do not hold monolithic attitudes towards the West and distinctions are made between various Western countries. They also prove that their attitudes are generally influenced and sometimes shaped by western countries' foreign policies. There is evidence that the Arab public disagrees with the foreign policies of the US and UK, in particular, and does not see the conflict with the West as a "clash of civilizations" nor as a struggle between "Crusaders and Muslims" (CSS, 2005 p. 2). Nevertheless, many hold positive views of the West and attribute positive traits to their cultures. Arabs do not see the West as a unified whole, and so attitudes towards the US and UK are usually focused on separately from the entire West since the Arab world is mostly influenced by these two nations' foreign policies and involvement in the Middle East.

Studies show that although many Arabs are disturbed by the US and British governments and their policies, they are impressed by their technological advancement, development, and freedom. Most studies reflect the general Arab public opinion of the West, but this study specifically focuses on the reactions of English majors towards the US and UK. The aim of this study is to examine the attitudes of Jordanian college students majoring in English Language and Literature towards the US and UK in particular as these two nations and their cultures are the most widely explored and discussed in the courses offered by the English department.

\subsection{East- West Attitudes}

The issue of Arab and Muslim attitudes towards the West has become the focus of many studies like Tessler (2002), Zogby (2002), Furia and Lucas (2006), and Esposito and Mogahed (2008), and Esposito (2011) particularly after 9/11. The United States in the past enjoyed a more favorable image in the Middle East than Europe did in the $19^{\text {th }}$ and early 
$20^{\text {th }}$ centuries, writes Alfred Prados in his 2001 report on US- Middle Eastern relations. He goes on to explain that at the time it hardly engaged in any wars with the Middle East and showed no colonial ambitions in the region, thus, American visitors or scholars were welcomed and highly respected there until this period of minimal involvement of the US came to an end after World War II. Since then the US has developed various interests in the Middle East and engaged in several wars with its people which affected public opinions of it. The tragic event on September 11, 2001 made relations even worse between the two cultures. This tragedy has also caused people to search for an answer for the question "why they hate us." In answering this question, many simply thought the conflict between the West and Arabs and Muslims was based on a long history of a "clash of civilizations" and a typical response has been that Islamic and Western societies are antithetical in their values (Esposito, 2011, p. 367).

Former president Bush was the main figure who reinforced this misinterpretation in his speeches to the public in which he would state that "Others" hold a grudge towards the USA because they are against the "American way of life," freedom, and democracy misleading many people to think it is Muslims who are against their style of life and are willing to attack others because of such a difference in culture and religion. The former President's relentless reinforcement of the division between "us" and "them" has created a high sense of hostility and animosity between the US and the Arab World. One of the more infamous examples was in his address to a joint session of Congress in 2001:

On September 11th, enemies of freedom committed an act of war against our country ... Americans are asking, why do they hate us? They hate what we see right here in this chamber-a democratically elected government. Their leaders are self-appointed. They hate our freedoms - our freedom of religion, our freedom of speech, our freedom to vote and assemble and disagree with each other . . Every nation ... now has a decision to make. Either you are with us, or you are with the terrorists.

Actually this notion of Muslims hating America and its freedom and democracy has been contested by senior analyst of the Gallup Center for Muslim Studies, Ahmed Younis, who found through a survey he helped direct that the number one response to what Muslims admired the most about America was technological advancement, followed by freedom and democracy (Bodily, 2012). In fact, the United States is seen as a "land of milk and honey" as well as a land of freedom and opportunity in spite of the fact that they sense Western hostility to Islamic society (Prados, 2001). Accordingly, this theory of the "Clash of Civilizations" has been tested and has failed repeatedly especially when studies such as Furia and Lucas (2008), Zogby (2002), Esposito (2011) have proven that Muslims and Arabs do not hate Westerners and do not have the same attitude towards all Western nations. According to Furia and Lucas (2008), the strongest support was found for the political hypothesis in their study that "hostility toward specific Western countries is predicted by those countries' recent and visible international political actions in regard to salient international issues" (p. 186). That is, many Middle Eastern countries may have more favourable opinions of certain western countries over others based on their actions and governments' policies thereby proving that it is not a clash of civilizations or values that fuels an animosity between nations. In other words, the Eastern and Western civilization may not share the same values but this has not been the cause of conflict between the two civilizations just as Arabs and Muslims have not had clashes with Asian civilizations in spite of some vast differences they have in faith, beliefs, political system, and style of life. As Furia and Lucas (2006) and the Zogby poll (2002) suggest, Arab opinions about Western countries have everything to do with specific countries' foreign policies and very little to do with a clash of civilizations. While Samuel Huntington's (1996) controversial theory on the clash of civilizations identifies the Islamic civilization as being the most likely to clash with the Western one, the results of the Abu Dhabi Gallup survey (2011a) have proven that religiosity and Islam are not barriers to Muslim- West relations as is often assumed, for many countries who say religion is important still rank high in their positive views about Muslim- West relations.

Younis points out several reasons behind Muslims' disagreement with Americans such as Muslims' belief that the US continues to "exercise political domination over other areas of the world." Cultural disrespect combined with political action was another reason mentioned for the conflict between Muslims and Americans and finally Muslims' perception of the United States as a "catalyst for war and instability" and their belief that America promotes conflict" (Bodily, 2012). There is also a wide perception among Arabs and Muslims that the United States respects the human rights of its own citizens and practices democracy within its borders but does not necessarily promote these values abroad (Prados, 2001, p. 8).

The survey published by CSS in Jordan shows that despite the dissatisfaction with the US and British policies, the Arab world desires stronger relations with the West. Arabs do not hold entirely negative views of the West for the findings show they have a much more positive attitude towards France, for instance. Only $25 \%$ of sample respondents report feeling either highly or moderately positive towards the US and UK as opposed to the $57 \%$ who feel more positively towards France. This is no surprise as they view the US and UK as violating human rights, "imposing their wills" on other nations, and promoting their own interests. Nevertheless, they associate the US and UK and the West in general with liberty, wealth, liberalism, and technological advancement. Esposito (2011) notes that Muslims admire America's democratic principles but believe the United States has double standards in its application and promotion of democracy and human rights since it has failed to apply such principles in its relations with the Arab region and treatment of Muslims. Many in Jordan and other Muslim countries sensed disrespect for the Islamic religion through Western cartoon depictions of the prophet as the Pew Global Attitudes Project (2006) shows.

The Gallup survey (2011b) focused on Islamophobia and anti- Muslim sentiment in the West reflects Muslims not feeling respected by the West. Findings reveal that several Western countries share this sentiment. Particularly, 38\% of Britons and 52\% of Americans say the West does not respect Muslim societies and this percentage is the highest 
compared to other Western countries with smaller percentages that agree. The survey shows that many Muslims believe they are treated unfairly due to Islamophobia existing in Western societies. In fact they are seen more often than not as intolerant and not accepting of other religions. Specifically, one in five Americans think most Muslims around the world are not accepting of other religions and of people of different races other than their own. The findings of The Pew Global Attitudes Project (2006) show similar results and indicate that Muslims are mostly seen by the West as fanatical and violent in addition to lacking tolerance while Muslims in the Middle East and Asia generally see Western societies as selfish, immoral, violent, and fanatical. Muslims in general believe the West is to be blamed for the strained relationship between the two parties.

In a recent 2012 article published by The Guardian, Leon Moosavi writes that xenophobia is pervasive in British society today leading Muslims to be seen as outsiders and potential enemies even if they have integrated into British society. There is evidence from a survey conducted at the University of Essex that nearly half of British society considers Muslims as a threat and 52\% believe they create problems in the UK. The most striking finding, however, is that $58 \%$ of Britons associate Islam with extremism (Moosavi, 2012). The YouGov poll (2010) found that $69 \%$ believe Islam encouraged the repression of women. The survey also indicates that $50 \%$ of British society associates Islam with terrorism while only $6 \%$ associate it with justice. Ironically, $60 \%$ admitted they did not know much about the religion and only 33\% would be interested in finding out more about it. The British Social Attitudes Survey published by NatCen, the UK's largest independent social policy research organization, reports in its 2010 report that there is far greater opposition to Islam than any other faith in the UK and that only a quarter of Britons have a positive attitude towards Muslims.

\subsection{Literature, Perceptions, and Attitudes}

Students learn about Western culture, its perceptions, and attitudes through reading the literature it has produced. Jordanian students majoring in English started to study American and British language and literature during school and continue to do so during college. Throughout the program, students learn to analyze, critique literary texts, and build arguments. As they read literature, they get exposed specifically to American and British cultures, values, traditions, and systems of thought and belief. In the process of their learning and constructing analyses, they may compare the two cultures to each other or to their own or form an image of them based on what they have read from their literary productions. Literature has always been powerful in the way it has been viewed as the "window to the world" and a reflection of a culture's history, and tradition (Sidhu, Fook, \& Kaur, 2010, p. 54). Sidhu et al. (2010) add that literature helps learners gain an understanding and appreciation of cultures and ideologies other than their own and increase their sense of tolerance to others. It makes them aware of differences in cultures and exposes them to the "other's" culture, attitudes, practices, and beliefs as they are often reflected in literary texts, thus enabling students to formulate their own perceptions and views as to how individuals of another culture relate to their experiences and form judgments about them (LaboPopoola, 2010, p. 52).

Many professors encourage and teach students to think critically about the societies represented in various literary texts. This continuous practice of critical analysis students undergo leads them to an awareness of the fact that "texts are not ideologically natural or neutral" and that some voices are represented while others are silenced (Luke \& Freebody, 1999). According to Figuiredo (2008), if students are introduced to a critical perspective of reading, they will gain insight into the represented culture and relations of social power since "texts bear traces of the discourses and ideologies of the institutions which produce them" (p. 139). This process of critical analyses brings students to a deeper understanding of the culture and the sociopolitical issues raised by the writers which eventually leads to the formation of certain images of that culture in students' minds.

Through their reading of American and British literature, students are likely to develop attitudes towards the two cultures whether positive, negative, or neutral, perhaps some will be conflicted about how they view them. According to Fishbein's and Ajzen's (1975) definition of attitude, it is "a learned predisposition to respond in a consistently favorable or unfavorable manner with respect to a given object" (p. 6). It is believed attitudes are an individual's reaction to or affective evaluation of the supposed facts about a situation reflecting a favorable or unfavorable opinion about the object or situation (Holden \& Edwards, 1989, p. 89-90). These definitions show that students are inclined to respond either favorably or unfavorably to the situations they read about in literary texts and the facts they learn through studying the history of American and British societies from various sources. Attitudes are actually seen as often reflecting multiple kinds and sources of information, thus, they can be conceived as summary evaluations of people, behaviors, or objects (Zanna \& Rempel, 1988). In practicing critical analysis and constructing critical arguments, students piece together various types of information, images, and situations they encountered from different sources and the American and British literary works they studied indirectly leading them to forming summary evaluations of people and traditions and forming attitudes towards the two cultures in general.

Research about student attitudes towards the English language and literature and studies about Arab public attitudes towards the West exist, but the significance of the current study lies in the fact that it focuses on the attitudes of Muslim Jordanian female students, particularly, majoring in English language and literature towards the US and UK.

\section{Research Questions}

Through the conducted survey and interviews with students, the study aims to address the following questions:

1-How do students of English view the US and UK, and why are they viewed this way?

2-How do these student attitudes toward the US and UK differ from those of the general Arab public? 
3-Does majoring in English language and literature affect how student attitudes toward the West are shaped?

\section{Method}

The main tools used for this study were a survey and semi- structured interviews during which students were asked about how they viewed the US and UK and if they had the same attitude towards the two countries. The general idea behind the study was explained to students to achieve a sense of comfort among them and objectivity at the same time. They were told their views would be reported in this study yet remain anonymous to which permission was granted.

\subsection{Participants}

The sample in this study included forty Muslim Jordanian female students majoring in English Language and Literature. The ages of these female students ranged from 20 to 22 years. They were in their fourth and last academic year, and have almost completed all the requirements for their major. The participants were exposed to literature and language through the credit courses they took at the Department of English. These students have never visited the USA or UK to have developed attitudes towards them based on their visits but have been exposed to these cultures through their study of the English Language and Literature and most likely the media.

\section{Results}

\subsection{Survey}

A survey was conducted to examine student attitudes towards the US and the UK. The survey revealed that $60 \%$ agreed that they see the West, in general, in a positive way, while 33\% disagreed, and $7 \%$ strongly disagreed with the statement. The next result indicated that $10 \%$ strongly agreed that they saw the UK in a positive way, $73 \%$ agreed, while $10 \%$ disagreed and $7 \%$ strongly disagreed. However, their views of the US were quite different. Those who think of the US in a positive way were $33 \%$, those who disagreed with that were $50 \%$ and $17 \%$ strongly disagreed with that. The next statement showed that $25 \%$ strongly agreed that they preferred to live in the UK rather than the US, $55 \%$ agreed, however, $13 \%$ disagreed and $7 \%$ strongly disagreed. As for continuing their education in the UK, $33 \%$ strongly agreed they preferred to do so in the UK rather than the US, and 55\% agreed, while $10 \%$ disagreed and only $2 \%$ strongly disagreed. The next question was about whether they felt studying Shakespeare and British literature improved their views of the UK with which $10 \%$ strongly agreed and $55 \%$ agreed, but $27 \%$ disagreed and $8 \%$ strongly disagreed. They were asked the same question but about American literature and its role in improving their perceptions of America with which only $10 \%$ strongly agreed and $58 \%$ agreed, however, $22 \%$ disagreed and only $10 \%$ strongly disagreed. The final statement was about how they think the West sees them as Muslim and Arab and whether it is in a positive way. The responses indicated that $10 \%$ strongly agreed that they thought the West sees them in a positive way, $20 \%$ also agreed, while $45 \%$ disagreed and $25 \%$ strongly disagreed with this.

\subsection{Interviews}

Semi- structured interviews were conducted to examine students' views of the US and UK and the reasons they give for holding such views. Views towards the US will be discussed first then those towards the UK.

\subsubsection{Attitudes towards the US}

The responses about the US can be categorized into three groups according to the content of these responses and the reasons given: first, negative views due to political and cultural reasons, second, positive views, and third, neutral.

The interviews indicated that a large number of students do not have favorable views of the US due to various political reasons. They believe Americans view Arabs and Muslims as terrorists and violent people; therefore, they mistreat them and discriminate against them. They also think Americans see them as enemies and hate them because they are Muslims and do not respect them as Arab or Muslim. This group thinks that the US rules the world, and can do horrible actions against other countries and no one can stop them. Students explain, the US wants to dominate the world and steal resources and oil of Arab nations, and the examples they give are the wars against Iraq and Afghanistan. Some think that the US interferes with political problems in the Arab region when it should not. Several students mentioned they were not happy with America's relations with the Middle East because they believe "it imposes its ideas on other nations, controls the rich countries, and oppresses their people through its imperialist agenda." One student stated that "America calls for peace while it is the one who is creating wars." Another mentioned, "The US thinks it is the best and others have to follow its rules." Other students criticized the US because of what they learned about the existence of racial discrimination against African Americans.

Some negative views of the US have been attributed to cultural reasons. A few students feel there is too much freedom in the US and this does not appeal to them as a way of life. Others said that American movies reveal that American values are very different from students' and do not agree with their own. They also thought that American media focuses much more on entertainment rather than education.

The next group of respondents were neutral or rather conflicted about how they view the US. Some believed it is a land of opportunity and development and many people in the world wish to live there, however, they did not think it was a great place for Arabs and Muslims because they do not think they are respected there. Others agreed that some Americans may disrespect Arab culture but others do not. A few others liked the democratic principles and standards of freedom practiced in the US, but think it would be difficult for Muslim women to live there because of the pressure they will face from society because of the Islamic veil. 
The last group held positive views of the US. They thought it offers its own citizens and people around the world great education and technology. Others thought it is the strongest country in the world and the most developed. A few thought Americans are friendly people but may not like Muslims for religious reasons. One commented that "America is a country that can help others to improve their situation and can offer many opportunities for advancement and people there respect each other and those who work in their country." Others wished they could interact with Americans their age to improve their image as Muslims and build positive relations with them.

\subsubsection{Attitudes towards the UK}

Interviews with students showed that most of them hold a positive attitude towards the UK and their responses fall under three categories according to the reasons given for such an attitude. The three main reasons students gave for their positive views of the UK are: first, British respect for other cultures, second, their comfort with British English as a language to study, third, their perception of the UK as a peaceful country that is not interested in dominating other nations.

The first group thinks that in the UK there is great respect for people from other cultures and the British respect Muslims and Arabs in particular. Some students think the British are tolerant to religious and cultural differences even if they do not believe in the same values. The second set of students believes British English is easier for them to learn than American English. They are also impressed by the UK's civilization and rich history and wish to continue their studies there. The third group thinks that the British are pacifists and are not interested in controlling other countries. They believe the UK had a lot of power in the past and ruled so many parts of the world but this is history and they are different today. They think "They no longer have that power and do not think of colonizing other nations, they just want to be the best through other means besides war."

\section{Discussion}

The findings of the study reveal that a high percentage of students have a positive attitude towards the West in general and the UK in particular while lower percentages were found to have positive feelings towards the US. These findings agree with Zogby (2002), Furia and Lucas (2008), and Esposito (2011) which assert that the Arab world does not have a monolithic attitude towards the West by any means. That is, while the Arab public has quite favourable attitudes towards some Western countries like France, it has unfavourable attitudes toward others like the United States so a generalization about all Western countries cannot be made. The results in the current study, however, do not agree with the findings reached by the CSS (2005) in Jordan which indicate that the Arab world is dissatisfied with both British and American foreign policies equally while only a quarter of respondents had positive views of them. That is, positive attitudes towards the UK have been found among a large number of students in the study. But Zogby's (2002), Furia and Lucas' (2006; 2008), and Esposito's (2011) suggestion that the political hypothesis that hostility towards specific Western countries has resulted from those countries' political actions in regard to various international issues in the Middle East and their foreign policies has been reaffirmed by the responses we received from our students in the current study.

The current study echoes the conclusions arrived at in Bodily's (2012) and the CSS (2005) study about Arab perceptions of the US as promoting conflict and imposing its will on other countries. Many students had expressed their discomfort with the role the US has been playing in the Middle East and perceived it as an interference to promote its own interests in the region. On the other hand, student responses indicated that they do not have a similar perception of the UK and do not view it the same way. This is contrary to the public view reflected in the CSS (2005) study as the Arab public had dealt with the US and UK as one entity holding similar views of both.

The admiration of the West for its technological advancement and values of democracy and freedom reflected in the Gallup (2011) and CSS (2005) studies has also been found to a great extent among our students. On the other hand, results collected about our student attitudes reassert the wide perception among the Arab and Muslim public that the US respects human rights and practices democracy within its own borders, thereby it practices double standards particularly in the Middle East as it does not apply these values abroad and not in the "other's" lands (Prados, 2001; Esposito 2011).

There is evidence that the subjects in our study, the students, do not feel respected by the US and neither is their culture or religion. These sentiments are justified as reflected in the Gallup (2011b) study which indicates that the highest percentages are found in the US and UK compared to other Western countries that confirm the West does not respect Muslim societies. In this case, students' feelings of not being respected by the US do not differ from those of the general Arab public and sadly these sentiments have been confirmed by some Westerners themselves who agree that anti- Muslim sentiments exist in the West, so the Arab world has sound reasons to believe so as often represented in Western media. In the study, students' held belief that their religion and culture is respected by the British contradicts the findings of the Gallup (2011b) study which reveals that $38 \%$ of Britons say the West does not respect Muslim societies. This belief is also questioned in light of the fact that $50 \%$ of British society links Islam to terrorism while $69 \%$ think it encourages the oppression of women, as the YouGov (2010) poll suggests. The Pew Global Attitude (2004; 2006) and British Social Attitude (2010) studies confirm our students' and Arab public's belief that they are seen by the West as violent and fanatical, and are associated with terrorism.

\section{Conclusion \& Implications:}

As can be seen from the findings, the "Why do they hate us?" question holds no grounds. The study confirms that Jordanian students of English and the Arab public in general do not hate the West and do not see it in entirely negative terms. Actually, many associate the West with development, technological advancement, and liberation; traits many of 
them admire. It is worth noting that although Arabs do not hate the West or the US, there is a widespread distrust of the US that is not unique to the Arab public but extends beyond the Middle East to include south Asia and several European allies such as Germany, France, and the UK, a YouGov survey found (Borger \& Clark, 2012). It was found that Germany was more sceptical than trusting of the US, whereas French and British opinions were more positive yet deeply divided. Although the survey reflected American affection to its British ally, there was British ambivalence about America's role in world affairs. However, two- thirds of the American respondents in the survey said they trusted the UK to "act responsibly" and the main traits they attributed to the UK were a respect for human rights and "a sensible voice in the world." Unfortunately, when British respondents were asked to choose a word they associated with America, $40 \%$ chose "bullying" and only $12 \%$ associated the US with respect for human rights (Borger \& Clark, 2012).

These findings prove that the negative sentiments among Arabs and Muslims toward the US are not based on a clash of Eastern and Western civilizations and that a distrust of the US is there within the West itself. Students of English and the Arab public do not believe the conflict between the West and the Arab World is caused by religious or cultural differences which is contrary to what some researchers, particularly in the US, have suggested. The findings indicate their disagreement is rather based on Western foreign policies, particularly represented by the US, and their political practices in the Middle East. The study also reveals that the attitudes held by students of English towards the US are similar to those of the general public in the Arab world. The UK, however, is perceived more positively by our students than the Arab public. Students think it is a peaceful country which no longer has any colonial or imperial interests in the region and lacks the power to repeat history or the past since it is not a super power any more. They are also under the impression that their culture and religion are respected by the British and that British perception of Muslims is more positive than American's. Unfortunately, the Gallup (2011b) survey shows evidence that disrupts such perceptions.

While English majors and the general public have the same attitude towards the US and its foreign policies, the discrepancy in opinions of the UK can be understood in light of the age factor of the participants in the study. Students may not agree with the general public in their negative feelings about the UK since their ages range between 20-22 years, and so they may not have sufficient knowledge of the British colonial legacy and history in the Middle East or its current role in world politics. But they have acquired enough information from various sources, and the media being one of them, about the current US presence and political interests in the region and its relations with the Muslim world (especially with Iraq, Afghanistan, and Palestine) leading them to favour the UK over the US.

The general public, on the other hand, holds different views because it naturally includes older individuals who most probably worked under the British rule at least during the first half of the $20^{\text {th }}$ century and have experienced the impact of British colonization first hand possibly. This colonial experience and memories of it have most likely remained in the public's consciousness and even been passed down to the next generation, thereby, affecting their attitudes towards the UK even if its current presence in the Middle East and the media is not as prevalent as the US is.

The findings suggest that specializing in the English language and literature does not necessarily change student attitudes towards the West but it does influence them. At the same time, it cannot be denied that the media will continue to have a major impact on the formation of the public's opinion of the West and students' of English as well. Studying the English language and literature may have reinforced students' previous conceptions of the UK and the US, and West in general. Furthermore, negative views towards the US by Arabs, studies show, result from feeling embittered and threatened by it, and so, once the threat is lifted, these negative attitudes are bound to disappear. The study reveals that positive attitudes towards American society and culture exist in the Arab world but a certain level of anger also exists towards the US government. These mixed feelings in the Arab region suggest that the US ought to demonstrate its dedication to principles of peace and democracy in its relationship with the Middle East and foreign policies in order to regain the trust of the general public in the Arab world and the Middle East at large.

\section{References}

Bodily, N. (2012, April 25). Understanding Muslim Views of the US: Pollster debunks Muslim Myths. Retrieved from http://www.usustatesman.com/understanding-muslim-views-of-the-us-1.2735354\#.UA3YA2FWqhE.

Borger, J. , \& Clark, T. (2012, Sept 11). Widespread distrust of US extends beyond Middle East, poll shows. The Gaurdian. Retrieved from http://www.guardian.co.uk/world/2012/sep/11/distrust-us-middle-east-poll.

Bush, G. W. (2005, Jan. 20). President Bush's second inaugural address. Retrieved from http://www.npr.org/templates/story/story.php?storyId=4460172.

Center for Strategic Studies. (2005). Revisiting the Arab street research from within. Amman, Jordan: University of Jordan.

Esposito, J.L. (2011). The future of Islam and U.S.-Muslim relations. Political Science Quarterly, 126, 365-401.

Esposito, J. L. \& Mogahed, D. (2007). Who speaks for Islam? What a billion Muslims really think. New York: Gallup Press.

Figueiredo, D.C. (2000). Critical discourse analysis: towards a new perspective of EFL reading. Critical Discourse Analysis, 38, 139-154.

Fishbein, M., \& Ajzen, I. (1975). Belief, attitude, intention and behavior: An introduction to theory and research. California: Addison-Wesley Publishing Company. 
Furia, P. \& Lucas, R. (2006). Determinants of Arab public opinion on foreign relations. International Studies Quarterly, 50, 585-605.

Furia, P. \& Lucas, R. (2008). Arab Muslim attitudes toward the west: cultural, social, and political explanations. International Interactions, 34, 186-207.

Gallup World Poll Knowledge Center. (2011a). The Abu Dhabi Gallup forum: Research, dialogue, and solutions. New York: Gallup Press.

Gallup World Poll Knowledge Center. (2011b). Islamophobia: Understanding anti-Muslim sentiment in the West. New York, Gallup Press.

Holden, G. W., \& Edwards, L. A. (1989). Parental attitudes toward child rearing: Instruments, issues, and implications. Psychological Bulletin, 106, 29-58

Huntington, S. (1996). The clash of civilizations and the remaking of world order. New York: Simon \& Schuster.

Labo-Popoola. S.O. (2010). The place of literature in the teaching of English language as a second language. The Social Sciences, 5, 49-54.

Lewis, B. (2003). The crisis of Islam: Holy war and unholy terror. London: Phoenix.

Luke, A., \& Freebody, P. (1999). Further notes on the four resources model. Reading Online. Retrieved from http://readingonline.org/past/past_index.asp?HREF=/research/lukefreebody.html

Moosavi, L. (2012, July 3). Muslims are well-integrated in Britain - but no one seems to believe it.The Guardian. Retrieved from http:/www.guardian.co.uk/commentisfree/belief/2012/jul/03/muslims-integrated-britain/print

Park, A., Curtice, J., Thomson, K., Phillips, M., \& Clery, E. (2010). British Social Attitudes: The 26th Report, London: Sage.

Pew Global Attitudes Project. (2004). A year after the Iraq war: Mistrust of America in Europe even higher, Muslim anger persists. Washington, DC: Pew Research Center for the People and the Press.

Pew Global Attitudes Project. (2006). Europe's Muslims more moderate. The great divide: How Westerners and Muslims view each other. Washington, DC: Pew Research Center for the People and the Press.

Prados, A. B. (2001, Dec 31). Middle East: Attitudes toward the United States. Retrieved from http://fpc.state.gov/documents/organization/7858.pdf.

Sidhu, G. K., Fook, C. Y., \& Kaur, S. (2010). Instructional practices in teaching literature: Observations of ESL classrooms in Malaysia. English Language Teaching, 3, 54-63.

Tessler, M. (2002). Islam and democracy in the Middle East: the impact of religious orientations on attitudes toward democracy in four Arab countries. Comparative Politics, 34, 337-254.

YouGov. (2010, May 21). Exploring Islam foundation. Retrieved from http://www.eifoundation.net/index.html

Zanna, M. P., \& Rempel, J. K. (1988). Attitudes: A new look at an old concept. In D. Bar-Tal, \& A. W. Kruglanski (Eds.), The social psychology of knowledge (315-334). Cambridge: Cambridge University Press.

Zogby International. (2002). The ten nation impressions of America poll. Utica, NY: Zogby International.

Zogby International. (2004). Impressions of America poll. Utica, NY: Zogby International. 